\title{
The Production of the Sexual Difference in Physical Education: Problematizing Naturalizations
}

| ${ }^{1}$ Eric Seger de Carmargo, ${ }^{2}$ Henrique Caetano Nardi I

\begin{abstract}
Researches that describe the anatomy and physiology of human movement have aimed to produce knowledge comparing women's and men's physical capacities, concerned with specifying and describing "sex differences." One of the consequences of this kind of research is that it influences teaching processes in human motion disciplines for physical educators, producing gender-marked bodies. This article uses Foucauldian discourse analysis to question how the production of sex differences is present in scientific studies dedicated to studying athletic performance that propose comparisons between sexes in strength performance. Through this analysis, we aim to describe and analyse how the epistemologies of sex and gender involved in these productions reinforce naturalised ideas of what it means to be a man and a woman, as well as question the social intelligibility of body/gender/sexuality that regulates sex/ gender in our culture and in science.
\end{abstract}

> Keywords: Strenght, Sex, Gender, Physical education.

\author{
${ }^{1}$ Universidade Federal do Rio \\ Grande do Sul. Porto Alegre-RS \\ Brasil (eric.w.seger@gmail.com). \\ ORCID: 0000-0003-0770-9832 \\ ${ }^{2}$ Universidade Federal do Rio \\ Grande do Sul. Porto Alegre-RS, \\ Brasil (hcnardi@gmail.com). \\ ORCID: 0000-0001-6058-1642
}

Recebido em: 29/07/2019 Aprovado em: 11/10/2019 Revisado em: 18/05/2021 


\section{Introduction}

Physical education is a discipline that deals with the various manifestations of body culture. Part of this culture refers to the physiological possibilities of producing strength, agility, and endurance in sports performance. To understand how those variables can be affected by training, there is a scientific production related to the production of muscle strength. Regarding gender as a category of analysis, the discipline has mostly produced differences in the way boys and girls are treated in educational practices (Dornelles, 2012). According to Dornelles (2012), there is also an age marker in the passage from childhood to early adolescence in which teachers perceive and produce the difference between boys and girls, separating activities in physical education classes, justifying it from naturalised notions of masculinity and femininity. The author also highlights that the intensity of physical activity is a relevant factor in how to signify gender in physical education classes. Physical fitness is directly related to the modulations of training variables such as intensity, therefore being a key issue in analysing gender and physical fitness.

Altmann (2016) reports that the teacher's performance is fundamental for the production of differences in the performance of activities during physical education classes. On the one hand, when the teacher believes that girls and boys should have different characteristics and behaviours in physical activity practices (such as insecurity, sensitivity, and passivity for girls, and courage and strength for boys), his/ her actions produce those groups with different characteristics. On the other hand, a class that does not emphasise those social markers of gender provides activities in which this mandatory separation is not observed. (ALTMANN, 2016).

Based on this brief introduction of how the relationship between sex and physical fitness influences school practice, creating an effect directly related to the construction of men's and women's bodies and identities, we propose here the analysis of articles that legitimise this sexual difference in the area of physical education and sport. This analysis is important for the theoretical basis that those articles are likely to provide teachers and for the effects of truth produced.

\section{Method and Core Concepts}

To describe the network of statements that constitute the notions of sexual difference and physical performance, the hypotheses and comparisons between sexes 
carried out by studies that aim to map physiological differences between "men" and "women" related to mechanisms of producing strength will be analysed.

Four articles were selected from keyword searches: "Sex differences AND strength," "força AND homens AND mulheres," "Male AND female AND strength" in the search engines: Google academic, Scielo and PubMed. The search was conducted in January 2019. Those who had in their title or abstract a result of the comparison between sexes of any of those mentioned abilities were selected. We considered the last 40 years, choosing one article per decade to observe a possible paradigm shift over time. Results that did not aim (or conclude) to relate physical fitness to gender/sex were discarded. Different strength test methods (isokinetic, muscle strength-1RM, dynamic) were selected. The selection aimed at analysing different epistemological paths chosen by each article, in a qualitative analysis of the scientific production available in the field.

The table below describes the characteristics of the articles in chronological order:

\begin{tabular}{|c|c|c|c|c|}
\hline Name & $\begin{array}{c}\text { Year and } \\
\text { Journal }\end{array}$ & $\begin{array}{c}\text { Number of } \\
\text { subjects }\end{array}$ & $\begin{array}{c}\text { Ability } \\
\text { analysed }\end{array}$ & Age group \\
\hline $\begin{array}{c}\text { Sex difference in muscular } \\
\text { strength in equally trained } \\
\text { men and women }\end{array}$ & $\begin{array}{c}1987, \\
\text { Ergonomics }\end{array}$ & $\begin{array}{c}47 \text { Men and } \\
50 \text { Women }\end{array}$ & $\begin{array}{c}\text { Muscle } \\
\text { strength } \\
\text { (Dynamic) }\end{array}$ & Adults \\
\hline $\begin{array}{c}\text { Sex difference in force } \\
\text { generation capacity during } \\
\text { repeated maximal knee } \\
\text { extensions }\end{array}$ & $\begin{array}{c}\text { 1996, European } \\
\text { Journal of } \\
\text { Applied } \\
\text { Physiology }\end{array}$ & $\begin{array}{c}37 \text { Men and } \\
27 \text { Women }\end{array}$ & $\begin{array}{c}\text { Isokinetic } \\
\text { strength }\end{array}$ & Adults \\
\hline $\begin{array}{c}\text { Impacto de oito semanas de } \\
\text { treinamento com pesos sobre } \\
\text { a força muscular de homens } \\
\text { e mulheres }\end{array}$ & $\begin{array}{c}\text { 2005, Revista } \\
\text { Brasileira de } \\
\text { Medicina do } \\
\text { Esporte }\end{array}$ & 23 Men and & $\begin{array}{c}\text { Muscle } \\
\text { strength } \\
(1 \mathrm{RM})\end{array}$ & Adults \\
\hline $\begin{array}{c}\text { Estudo comparativo da } \\
\text { força muscular da máo entre } \\
\text { cadetes homens e mulheres } \\
\text { da Força Aérea Brasileira }\end{array}$ & $\begin{array}{c}\text { Fisioterapia e } \\
\text { Pesquisa }\end{array}$ & $\begin{array}{c}17 \text { Men and } \\
14 \text { Women }\end{array}$ & $\begin{array}{c}\text { Palmar grip } \\
\text { strength and } \\
\text { types of } \\
\text { pinching }\end{array}$ & Adults \\
\hline
\end{tabular}

The research problem focuses on the analysis of the enunciative network that justifies the division and comparison of physiological aspects of so-called male bodies and socalled female bodies, as well as the possible effects of this division as a component 
of gender performativity (BUTLER, 2003). Thus, we seek to list the elements that constitute the logic of the division of sexes and to visualise their possible effects on education, where there is a pedagogy of the sexed body and the differentiated gender rules (LAUREL, 1999), being in physical education more specifically related to a biological differentiation between "sexes" (ALTMANN; AYOUB; AMARAL, 2011).

The concept of gender will be used from Butler (2003), i.e., that sex itself is not a datum of nature prior to the construction of gender, since the gender marking of bodies is the intelligibility matrix that builds this body. Since there is no body prior to culture, and the bodies are all marked by the matrix sex, gender, and desire, both gender, thought here as a cultural product of the differentiation of sexual bodies (SCOTT, 1995) and sex, are performative, that is, built through iterative repetition of speech acts and the rules around body practices (BUTLER, 2003). Thus, the reading of bodies through sex, called biological, materialises and makes possible their existence, through the repetition of ideas such as "boys stand up to urinate," "girls sit down to urinate," "boys are more aggressive," "girls need less movement.".

However, this does not mean that bodies do not have specific physiological characteristics related to what medicine and biology have been calling "sex" (LAQUEUR, 2001; FAUSTO-STERLING, 2000). The objective here is to verify how the physiological characteristics related to sexual bodies have been analysed in articles that seek the sexual difference in muscle strength activities. Is it possible to investigate the relationship between physical abilities without linking physiological characteristics to sex/gender? Is it always sex/gender that defines the result in a given physical capacity, in this case, strength? Does the model of analysis that uses sex as a stable and binary datum when taking as given a supposed nature constitute one of the enunciative acts that materialise the performativity of sex/gender?

As stated, the analysis of statements (FOUCAULT, 1986) that make up the discursive networks of the articles that seek to highlight and compare that difference between genders will be used. Thus, we seek to question the games of truth in the scientific discourses related to exercise. This study will discuss the limits and possible ruptures of the statement "biological sex," considering that it may be related to the production of hierarchies between human beings (BUTLER, 2003).

To analyse how truths are constructed, we must describe the spatiotemporal conditions that allow their emergence and determine the fundamental statements that define their construction and the corresponding discursive practices: 


\begin{abstract}
We will call discourse a set of utterances, insofar as they are based on the same discursive formation. It does not form a rhetorical or formal unit, indefinitely repeatable and whose appearance or use we could point out (and explain, if applicable) in history; it consists of a limited number of utterances for which we can define a set of conditions of existence. Thus understood, discourse is not an ideal and timeless form that would have, moreover, a history; the problem does not consist in knowing how and why it could emerge and take shape at a certain point in time; it is, mutually, historical - a fragment of history, unity, and discontinuity in history itself, which poses the problem of its own limits, of its sections, of its transformations, of the specific modes of its temporality, and not of its abrupt emergence amid the complicity of time. (Foucault, 2008, p. 132-133)
\end{abstract}

The forms of legitimation of science through research, as analysed here, can point out the forms of enunciation made illegitimate in real games. Thus, we seek to understand how the statements about "biological sex" are configured as a truth produced by various discourses and, thus, can manifest themselves in the field of education in the form of differentiated practices that produce materiality, and what is performed from there, in terms of intelligibility of bodies.

It is this matrix of thought that will be used in the analysis of the articles, reading with strangeness the direct, natural, stable relationship, previous to the body. This thought here as construction culture of masculinity and femininity attributed to the bodies as well as the stability of what is called "biological sex" from a chain of physiological markers such as hormone rates, body composition, and muscle morphology.

\title{
Description and discussion of the results
}

The first article, published in 1987, sought to highlight differences in strength by comparing men and women described as equally trained. The subjects considered had long-standing experience in swimming training, with early training in childhood. The average training per day in $\mathrm{km}$ was different between men and women, being $9.72+-2.7$ for men and $7.34+-3.5$ for women. This difference was not considered enough to disqualify the suggestion that the subjects were "equally trained."

The initial hypothesis is that the difference between genders in relation to strength would be explained by muscle mass. Thus, the strength measurements were compared with a correction in relation to fat-free mass and muscle diameter. With this, it would be a comparison between equivalent amounts of muscle mass. The choice of subjects with similar training histories aimed to minimise the factor of social differences between the sexes and mainly reflect biological differences. 
First, concerning the analysis, considering the concept of gender proposed by Scott (1995), as socially constructed differences to which people are subject, recognised from sexual bodies from the men's and women's political identities of the individuals surveyed, we can think that there has been gender training since birth. Do differences in how men and women are treated interfere with body patterns regarding strength? The article does not consider this effect of gender training. Instead, it considers that training since childhood and the average mileage per day is sufficient to determine that subjects are equally trained.

Thus, even if swimming training is "equivalent", there are two factors to be considered in data analysis: 1) gender training since childhood, which interferes with movement patterns, from self-identification with the production of masculinities and femininities, and 2) subjects' self-identification with these gender patterns. Recalling the gender perspective from Butler (2003), which places gender as a repeated performance or even a stylised repetition of acts, which is not just individual but also has a temporal and collective dimension, there is a consequence in the bodily construction of bodies from gender as a consolidating element of the subject.

At no point in the article is there this reflection or an indication of how much the people surveyed identify themselves with what is considered masculine or feminine. This can be an important fact because, if the social differences produced by the identification with one or another gender influence the corporeal construction, then it would be important to visualise the approximation (or not) of the subjects with this normative production of gender. Thus, one could scale whether or not these self-attributions of identity are responsible for a stronger profile.

Also, identification with masculinity or femininity since childhood interferes with decision-making in relation to body performativity. Altmann (2016) points out that the motivation for performing in activities in physical education class may be different according to the teacher's conduct, whether he/she is inclined to perceive and incite differences related to gender.

Another important excerpt for the analysis is found in the objectives of the article, which are:

(1) determining the magnitude of the sexual difference in strength in the upper and lower body in groups of men and women with a similar history of physical activity and (2) determining the extent to which the sexual difference in strength is explained by differences in lean mass (fat-free mass) and muscle diameter area. By deduction, the part of the sexual difference in relation to strength that is not explained by lean mass 
and muscle diameter area could be attributed to neuromuscular and/or other factors. (BISHOP, 1987, p. 676, our translation ${ }^{1}$ )

Also: "Because of the sexual differences in body size, it was necessary to adjust the potential inherent differences in fat-free mass and/or strength per muscle crosssectional area."

First, as the "equivalent" training hypothesis is accepted, performance differences are attributed entirely to biological factors: lean mass and/or neuromuscular factors. However, it is noticeable that, as the initial hypothesis of the article, it is already assumed that there is a biological difference between the sexes that causes this discrepancy. The question here is: can this difference be meant from the given "sex" as a nominal qualitative variable, which has the characteristic of mandatorily imposing a well-defined and always equal profile on the subject marked by it? That is, do all subjects marked as male necessarily have the same relationship of size, lean mass, and physical fitness, as well as the subjects marked as female? If the data "lean mass" and/or "size" were considered as part of a continuum, without being linked to a pre-discursive male or female imprint, would it be possible to predict strength performance in the same way?

Based on the results of the study, which say that differences in strength can be explained as a function of fat-free muscle mass much more than by the variable sex, we can think that the logic used by the article requires that the data on lean mass and size be considered as a direct consequence of the biological sex imprint. There is no other possible meaning for these biological data outside this relationship between opposing binary discrete quantitative variables. This choice of use of the sex variable acts in maintaining the intelligibility of biological sex as necessarily related to previously known amounts of physiological elements (such as fat-free muscle mass and size).

The second article selected for analysis is a study on sexual differences in the generation of the strength required for maximal repetitions of knee extension. The study measured the number of consecutive maximal repetitions of this movement, and throughout the trial, the mean strength per five repetitions. The percentage of strength decline was calculated from the first 50 contractions. The sample consisted of 63 people, including 36 women and 27 men. The muscle cross-sectional area was measured. 
The results of the article show that the percentage of decline is related to the value of the muscle cross-sectional area, which was expected, considering previous publications. Regarding the difference between the groups, the results showed that the percentage of strength decline was the same for both groups. However, it indicated that, if only the first five attempts were observed, the women's group had a greater decline.

On the hypotheses of the causes of differences: it is likely that the influence of sexual hormones may be responsible for sexual differences in anaerobic performance. However, there is no measure of the quantity of those hormones in the subjects studied. There is an assumption that the amounts of hormones in each subject are already known from the nominal qualitative variable "biological sex." Although there are mean values expected from this marker, it would be appropriate to propose such a correlation that the measurement of hormone concentration appears to support this argument, and it is then possible to trace a linear relationship between hormone concentration and strength decline. In this sense, again, the qualitative variable (biological sex) seems to have the effect of a quantitative variable, because it corresponds to a given amount of hormone levels. All subjects are assumed to correspond to a normative range of sex hormones, but this is not evidenced in the study, i.e., it produces in a performative act by stating that these are the possible quantities and that they produce this effect on the production of force, without the possibility of a spectrum of effects or the demonstration of direct correlation through the measurement of hormones and strength production.

In discussing the results, the authors mention that they do not know why women presented a lower percentage decline but inform that other researchers found differences related to types of muscle fibre, muscle metabolism indexes, and anaerobic performance between men and women. A brief review of previous studies is presented, and the following conclusion is stated:

In light of the previous data on the influence of muscle fibre composition and/or muscle metabolism on anaerobic performances, it seems challenging to explain the result presented, as well as the sex differences of the $\mathrm{D}$ and the $\mathrm{F}$. In short, the ability to generate strength during repeated maximal contractions had a high correlation with the muscle cross-sectional area regardless of sex. (KANEHISA, 1996, p. 561, our translation ${ }^{2}$ )

Previous investigations, which pointed out different muscle compositions "between sexes," were not considered relevant to explain the result. The conclusion 
is that sex is not a variable that alone influences the generation of strength but rather the muscle cross-sectional area. Thus, the article reinforces the naturalisation of the sexual difference in the construction of the research, even after concluding that it is not determinant for the production of strength. Could it be possible to enunciate a model of strength behaviour based only on the cross-sectional area without attributing it to the biological sex?

Based on this conclusion, however, the authors decided to close the article as follows:

\footnotetext{
The present results, however, indicate that women showed a lower strength production when compared to men, even when expressed per muscle unit of the muscle cross-sectional area. Women also had a higher percentage of strength decline than men when the strength produced by muscle area from the first to the fifth contraction was compared. (KANEHISA, 1996, p. 561, our translation)
}

First: what is the performative effect of deciding to end the article with this statement, highlighting the first five contractions? Is it to reiterate the notion that women are weaker? We observed that the conclusion highlights the part of the study that found lower values for women. As for lower strength production, even when expressed per muscle unit, would it be possible to definitively trace "being a woman" as a cause for this strength difference in a different research design? Or the design leads the reader to this kind of conclusion?

From this narrative choice, the fact that sex was a variable that influenced less in the generation of strength than the cross-sectional area is not placed as equally important for the conclusion. For future studies, we suggest that the area be used as a predictor of strength or be compared with performance without necessarily being correlated with sex. However, the end of the article performs the political choice by correlating lower strength production with the social and political identity of "being a woman." By writing the article in this way, they make statements that perform gender and sex performativity work, looking for its sense through measures of difference, the only way to understand the mechanisms of strength production for men and women. There is no production of "genderless" or "sexless" strength.

The objective of the article is to measure differences "between sexes," and, therefore, it would not make sense for this reasoning to dismember the variables to represent the functioning of the strength without the intelligibility filter "biological sex." However, through this possibility of representation, it is evident that the goal 
of comparing the sexes is part of the performative acts that produce the sexual difference in the field of physical education and sport. Instead of being an essential difference of the bodies, before the measurement, it is produced from the regimes of the cultural production of the bodies (GOELLNER, 2003) and by the statements with effect of truth on the physical capacities. The utterance that is repeated in this network would be "women are weaker than men."

This effect is verified through measures that select subjects self-identified with this production of gender who have undergone subjectivation processes marked by these regimes of construction of bodies legitimised (or made intelligible) in the conceptual corpus that supports trainings such as those analysed. The articles conclude that "women are weaker than men," and, therefore, either the women subjectively construct themselves as weaker than men or they will have their femininity questioned. A selffulfilling prophecy. Men need to build their strength above the level they acknowledge as the "women's" level, otherwise, their identities will be at risk.

Considering the marker "sex," the production of strength resulting from the marked individuals is established as specific to this assigned sex. Thus, the possibility that this production be the result of a set of factors not necessarily linked to this initial marker is denied.

The third article uses a power training (PT) protocol for eight weeks in a sample of men and women. It compares both the effect of training and the differences in results between groups. The justification for such a comparison is:

Although there is extensive literature indicating relevant changes induced by the practice
of PT programs, the magnitude of those changes when men and women undergo the same
type of training program is still not clear, since most studies have involved subjects of only
one sex, and the protocols adopted were quite differentiated. (DIAS, 2005, p. 225)

Then, would studies involving only one sex not be appropriate to describe the mechanisms of power training in another sex? The epistemological model indicates that the analysis of the strength production would necessarily be linked to one sex. Regarding the article in question, we highlight:

Although the mechanisms involved in the different responses found between genders for muscle strength are not yet well defined, it seems that the initial differences in training levels can decisively influence the results. Although this variable was not controlled in the present study, it is believed that, as a rule, the level of most women's physical activity is lower than that of men. In this sense, we would expect the most significant increases in muscle strength resulting from PT programs to occur in women (17), which was actually confirmed in this study. (DIAS, 2005, p. 227) 
Again, we reiterate that it is not exactly known what mechanisms cause the different responses found between these two groups. An important fact is that the level of physical activity related to the construction of gender was not estimated; however, the study believes that "as a rule, most women" have a lower level of physical activity than men. According to the theoretical model (naturalised assumption) proposed, this would explain the results found, but without controlling this measure, it can only be considered that it is an assumption.

The concluding remarks of the study states:

However, women showed an increase in muscle strength proportionally higher than that
observed in men in the three exercises investigated, which suggests that women seem to
have more significant potential for developing muscle strength than men after short pe-
riods of PT. We believe that these differences can be attributed, at least in part, to lower
initial levels of training of the women analysed and/or to a higher contribution of neural
factors in females. (DIAS, 2005, p. 227)

The women in the study had a specific effect on power training when compared to men. The conclusion of the study is, therefore, assumed, as the differences in the level of training and the difference in neural behaviour in the "female sex" were neither proven nor measured. A set of 15 women, which was not characterised by any data regarding culture, gender regulation, hormones, chromosomes, lean mass, metabolism, and other markers, undergoes a training protocol, and the result found is attributed to the "female sex." A retroactive effect of the universal construction of the so-called "biological sex" is evident, since the influence of the neural system was an assumption of the study based on another result, but from the conclusion, it acquires an effect of "truth of the biological sex." This process can also be verified in previous studies, which also report differences without proof of physiological mechanisms that justify the results observed, but which, at the end of the study, also state a truth of sex, the influence of such mechanisms on the effects of protocols.

The fourth article, called "Estudo comparativo da força muscular da mão entre cadetes homens e mulheres da Força Aérea Brasileira" (Comparative study of hand muscle strength between male and female cadets of the Brazilian Air Force), compares palmar grip strength and three types of pinching, with 16 male and 14 female subjects. The research protocol involved the random selection of those subjects, and the number of women in the Air Force academy was much lower (women's entry in the Air Force is very recent). This fact alone demonstrates social effects in relation 
to gender. One of the main objectives of the article was to show evidence that being a woman does not impede them from performing motor tasks while flying a plane.

Some of the theoretical assumptions that permeate the research hypotheses for the execution of the protocol are: "In the upper limbs, the responses to physical training indicate sex differences in strength gain, showing that, although the muscles of men and women have the same composition, men' muscle diameter is greater."

Again, we see in the scientific production a repetition that the muscles of men and women have the same composition, however, differences in muscle diameter. Can training influence this characteristic? The authors say: "Muscle hypertrophy involves modifications such as an increase in the muscle cross-sectional area involved, muscle fibre type, muscle volume, and protein synthesis." Then, from the literature presented, the answer is yes. From this connection, is it possible then that in this type of study different training levels are being compared instead of morphologically different groups in essence? The article says:

This is probably due to morphological and anatomical differences between the sexes, such as the area and diameter of the muscle fibres, which are greater in men than in women; and this difference is more significant when comparing young adults - age group of the cadets in this study. Another probable cause may be the increase in gene expression of specific genes present in muscles in response to exercise in the male population. (TEIXEIRA, 2009, p. 146)

The study does not propose as a hypothesis the cultural differences that permeate the construction of the bodies of each individual. The interpretation of the difference lies in morphological, anatomical, and genetic differences, which coincidentally are also related to the training and corporeal experience to which these populations are subjected. In the article itself, it is possible to glimpse the context of previous training to which the groups were subject:

An important consideration in the comparison between the sexes is the pre-training values. The absolute value of pre-training strength in men is higher than in women, but they respond more than the relative levels of strength increase. Therefore, despite the differences, the muscle strength values of the female cadets do not prevent them from controlling the aircraft. (TEIXEIRA, 2009, p. 146)

We noticed that the groups compared were not only differentiated by stable and well-defined morphological factors, but also as groups that had different training since childhood due to gender subjectivity. The impact of this subjectivity on each subject does not appear as a predictor in the model that the research uses. Instead, 
the discursive effect of comparing these terms is the repetition of an essential morphological difference that would explain the subjects. Without this view, the logic of the article would not make sense.

\section{Final Considerations}

From the articles analysed, it is possible to summarise some characteristics of this enunciative network that supports "biological sex" as stable and well-defined data, as well as the intelligibility that is built using this data in the historical context in which it is used.

\section{"Biological sex" is naturalised in data that are not measured.}

When the research uses the "biological sex" data, it assigns mandatory implications to the subjects in the form of physiological and morphological characteristics. Such as, for example, the greater or lesser amounts of hormones, muscle mass, and cross-sectional area of the muscle. Some of those data (such as hormones) are never measured in the study; they are well-known assumptions and used to explain the results observed. The measure of muscle mass appears, but it reproduces a difference in quantity as an immutable datum, i.e., the group entitled as "women" always has a lower average, which is established as a biological truth prior to the culture. When studies equate some of those variables (such as absolute strength or mass), the differences are minimised or almost nonexistent. However, this is never enough to abandon the hypothesis that there is an essential morphological difference between the so-called "biological sexes," since this is the main truth effect of the utterance.

Those numerous characteristics gain social meaning and unification through their articulation in the sex category. In other words, "sex" imposes an artificial unit on an otherwise discontinuous set of attributes. As discursive and perceptive, "sex" denotes a historically contingent epistemological regime, a language that forms perception, forcibly modelling the interrelationships by which physical bodies are perceived. (BUTLER, 2003, p. 199)

This utterance composes a performative act that builds the truth of the bodies. The use of "biological sex" is a pre-established intelligibility filter that is never questioned, even when the data indicate that it is not a stable factor in the characteristic analysed 


\section{The observation of an effect that is taken as a cause.}

The different results of the groups marked as "men" and "women" in relation to strength performance can be thought of as the effect of a - social - gender training. (GOELLNER, 2003) However, the logical path supported by the articles is that this observable difference is part of the essential constitution of the body and, therefore, would be part of a nature that would cause the difference observed. To support this argument, shortly after finding differences in means, the discussion points to differences in the corporeal constitution, supported by the same logic of previous intelligibility, when trying to establish a causal relationship between those studies that point out morphological differences and the result observed of performance differences.

When considering physical capacity measures as "natural" of the "being a man" or "being a woman" that causes this effect, the articles do not consider the social punishments that regulate the subjects by gender regulations. Thus, the body is naturalised as the origin of gender and not another possibility.

\section{The displacement of the social effect of gender to a biological substrate}

As demonstrated by Laqueur (2001) and Fausto-Sterling (2000), the truth about biological sex has been modified over time. Going through a stage in which social differences were considered fundamental to understand what gender was, which was later modified to a biological substrate (LAQUEUR, 2001). This is noticeable in the arguments of those articles. None of them provides a quantification for the social effect of the observed differences in strength performance. Many of them do not even consider that this difference may be related to social issues. Even those who consider this hypothesis do not propose tools to quantify the responsibility of social issues in the effect observed. Instead, they fall on the biological substrate and try to establish its relationship with the observed. In this way, there are many contradictions, because studies that do not corroborate the same conclusions are cited, but at the end of each article, the untouched truth is that women are people with a specific corporeal profile (hormones, chromosomes, amount of muscle) and are essentially weaker than men. Thus, a reality is built in which "biological sex" is a datum that exposes absolutely the whole truth of a body as if there were no contradictions between the amounts of hormones, chromosomes, and muscle mass. 


\section{The limited intelligibility of bodies from this system.}

How do you deal with someone whose "real sex" is not known? If the measure of the study depends on this data, it is not all subjects that can be part of what is produced as human. Intersex people, for example, go through a set of medical practices to have their "true sex" decided (MACHADO, 2005). Often people do not know what sex to assign to a transgender person ${ }^{3}$ (JESUS, 2014). In Brazil, situations that are perceived as deviations from the gender norm make people the target of prejudice (COSTA et al., 2013). This also happens in the school environment. When research takes as intelligible only bodies that follow a given pattern, it becomes impossible to think of equal rights for people who build their body and identity in models other than that pattern.

There is no gender ontology on which we can build a policy because gender ontologies always operate within political contexts established as normative injunctions, determining what qualifies as intelligible sex, invoking and consolidating reproductive restrictions that weigh on sexuality, defining the prescriptive requirements through which sexual bodies and bodies with gender marks acquire cultural intelligibility (BUTLER, 2003, p. 256).

To be part of the sample of human beings that produce muscle strength and constitute those sexual differences, is it necessary a corporeal prerequisite where there is stability between the sex designated at birth and the construction of sex/ gender? Do the results obtained by the research only make sense to those humans? The network of utterances indicates that they do.

Thus, from this analysis, we can conclude that the datum "biological sex" used by the articles analysed reinforces a binary model of a sexualised body that only makes sense from a chain of meanings of body (sex)/gender/sexuality (BUTLER, 2003). It is from these enunciative strategies that it is possible to construct the idea of biological sex as fundamental to understand the production of muscle strength, having as first criterion this datum to make intelligible the chain between body (amount of muscles, hormones, etc.) and gender (accomplishment, performance, motivation, access to training, etc.).

Studies on the accomplishment of physical abilities need to consider the possibility of a model that is not based solely on the idea of stable and well-defined biological sex so that it is possible to understand a broad matrix of possibilities of corporeal construction. 


\section{References}

ALTMANN, H.; AYOUB, E.; AMARAL, S. C. F. Gênero na prática docente em educação física: "meninas não gostam de suar, meninos são habilidosos ao jogar"? Revista Estudos Feministas, Florianópolis, v. 19, n. 2, p. 491-501, ago./2011.

ALTMANN, H.; MARIANO, M. (2016). Educação Física na Educação Infantil: educando crianças ou meninos e meninas? Cadernos pagu (46), janeiro-abril de 2016

ANDRES, S. S.; JAEGER, A. A.; GOELLNER, S. V. Educar para a diversidade: gênero e sexualidade segundo a percepção de estudantes e supervisoras do programa institucional de bolsa de iniciação à docência (UFSM). Rev. educ. fis. UEM, Maringá, v. 26, n. 2, p. 167-179, Junho 2015.

BISHOP, P; CURETON, K.; COLLINS M.(1987) Sex difference in muscular strength in equally-trained men and women, Ergonomics, 30:4, 675-687.

BRACHT, Valter. Epistemologia, ensino e crítica: Desafios contemporâneos; in Gomes, Ivan Marcelo. Epistemologia, ensino e crítica: desafios contemporâneos para a Educação Física. Nova Petrópolis: Nova Harmonia, 2013. p. 19-30.

BUTLER, Judith P. Problemas de gênero: feminismo e subversão da identidade. Rio de Janeiro: Civilização Brasileira, 2013.

CASTEJON, Francisco Javier; GIMENEZ, Francisco Javier. Teachers' perceptions of physical education content and influences on gender differences. Motriz: rev. educ. fis., Rio Claro, v. 21, n. 4, p. 375-385, Dez. 2015.

COSTA, A. B., Peroni, R. O., Bandeira, D. R., \& Nardi, H. C. (2013). Homophobia or sexism? A systematic review of prejudice against nonheterosexual orientation in Brazil. International Journal of Psychology, 48(5), 900-909.

DIAS, R. M. R. et al. (2005). Impacto de oito semanas de treinamento com pesos sobre a força muscular de homens e mulheres. Revista Brasileira de Medicina do Esporte, Vol. 11, No 4, Jul/Ago. DORNELLES, P. G. (2012). Do corpo que distingue meninos e meninas na educação física escolar. Cad. Cedes, Campinas, vol. 32, n. 87, p. 187-197, mai.-ago. 2012.

FAUSTO-STERLING, Anne. (2000), Sexing the body: gender politics and the construction of sexuality. Nova York, Basic Books.

FOUCAULT, M. A Arqueologia do saber. Rio de Janeiro: Forense, 2008, $7^{\text {a }}$ edição.

GOELLNER, S. A produção cultural do corpo. In: LOURO, G.L. et al. Corpo, Gênero e sexualidade: um debate contemporâneo. Petrópolis: Vozes, 2003.

HICKS, A.L., J. KENT-BRAUN, and D.S. DITOR. (2001) Sex differences in human skeletal muscle fatigue. Exerc. Sports Sci.Rev., Vol. 29, No. 3, pp. 109-112. 
JESUS, J. G. (2014). Transfeminismo: Teorias e Práticas. Rio de Janeiro: Metanoia.

KANEHISA, H; OKUYAMA, H; IKEGAWA, S; FUKUNAGA, T. (1996) Sex difference in force generation capacity during repeated maximal knee extensions. Eur J Appl Physiol, 73:557-562.

LAQUEUR, Thomas. Inventando o sexo: corpo e gênero dos gregos a Freud. Rio de Janeiro: Relume Dumará, 2001.

LOURO, G. L. (1999). Pedagogias da sexualidade. In: Louro, Guacira Lopes. O corpo educado: pedagogias da sexualidade. Belo Horizonte: Autêntica.

MACHADO, Paula Sandrine. O sexo dos anjos: um olhar sobre a anatomia e a produção do sexo (como se fosse) natural. Cad. Pagu, Campinas, n. 24, p. 249-281, Junho 2005.

OUDSHOORN, Nelly. (1994), Beyond the natural body: an archeology of sex hormones. Londres/Nova York, Routledge.

Schiebinger, L. (1986) "Skeletons in the Closet: The First Illustrations of the Female Skeleton in the nineteenth-century Anatomy," Representations 14: 42-83.

SCOTT, Joan. Gênero: uma categoria útil de análise histórica. Educação e Realidade. Vol.20 (2), jul/dez.1995: 71-100.

TEIXEIRA, M. D. M. et al. Estudo comparativo da força muscular da mão entre cadetes homens e mulheres da Força Aérea Brasileira. Fisioterapia e Pesquisa, São Paulo, v.16, n.2, p.1437, abr./jun. 2009.

\section{Notes}

${ }^{1}$ The purposes of this study were to determine: (1) the magnitude of the sex difference in upper- and lower-body strength in groups of men and women with similar backgrounds of physical activity and (2) the extent to which the difference in strength could be explained by indices of muscle size.

${ }^{2}$ In the light of previous data concerning the influence of muscle fibre composition and/or muscle metabolites on anaerobic performances, it seems to be difficult, therefore, to explain the present result as to the sex differences in the $\% \mathrm{D}$ of $\mathrm{F}$.

${ }^{3}$ Here, a trans person is understood as a person who had a sex assigned him/her at birth but who, throughout his/her life, built a gender and sex identity different from the one designated. 


\section{Resumo}

A Produção da Diferença Sexual na Educação Física: problematizando naturalizaçóes

Pesquisas que descrevem a anatomia e fisiologia do movimento humano têm objetivado produzir comparaçôes entre capacidades físicas de homens e mulheres, para especificar e descrever "diferenças sexuais". Uma das consequências desse tipo de pesquisa é sua influência em pedagogias de ensino utilizadas por profissionais da educação física, produzindo a materialidade do gênero nos corpos. Esse artigo utiliza análise do discurso Foucaultiana para interrogar como a produção de diferenças sexuais ocorre em artigos científicos dedicados ao estudo de desempenho físico que comparam os sexos em relação à força. Através dessa análise, objetivamos descrever e analisar como epistemologias de sexo/gênero estão envolvidas nessa produção de forma a reiterar ideias naturalizadas do que significa ser homem e ser mulher, assim como também questionar a inteligibilidade de corpo/gênero/ sexualidade que regula a materialização do sexo/gênero na cultura e na ciência.

> Palavras-chave: força; sexo biológico; gênero; educação física. 